OPEN ACCESS

Citation: Wong Sin Yeng, Boyce P.C. (2020) Studies on the Alocasia Schott (Araceae) of Borneo III: Alocasia puncakborneensis, a new species belonging to the Princeps Complex. Webbia. Journal of Plant Taxonomy and Geography 75(1): 111-115. doi: 10.36253/ jopt-7946

Received: January 29, 2020

Accepted: April 28, 2020

Published: June 30, 2020

Copyright: (c) 2020 Wong Sin Yeng, Peter C. Boyce. This is an open access, peer-reviewed article published by Firenze University Press (http:// www.fupress.com/webbia) and distributed under the terms of the Creative Commons Attribution License, which permits unrestricted use, distribution, and reproduction in any medium, provided the original author and source are credited.

Data Availability Statement: All relevant data are within the paper and its Supporting Information files.

Competing Interests: The Author(s) declare(s) no conflict of interest.

Funding: This is part of an ongoing research project funded by the Sarawak State Government Vote No. F07/NRGS/RIMC/2019.

Editor: Lia Pignotti, University of Florence, Italy

\section{Studies on the Alocasia Schott (Araceae) of Borneo III: Alocasia puncakborneensis, a new species belonging to the Princeps Complex}

\author{
Wong Sin Yeng ${ }^{1,2,3, *}$, Peter C. BoyCE ${ }^{3}$ \\ ${ }^{1}$ Institute of Biodiversity and Environmental Conservation, Universiti Malaysia Sarawak \\ 94300 Kota Samarahan, Sarawak, Malaysia \\ ${ }^{2}$ Harvard University Herbaria, 22 Divinity Avenue, Cambridge, MA 02138, USA \\ ${ }^{3}$ Department Biologie I, Systematische Botanik und Mykologie, Ludwig-Maximilians- \\ Universität München, München, Germany \\ *Corresponding author. E-mail: sywong@unimas.my
}

\begin{abstract}
Alocasia puncakborneensis is described and illustrated as a new species of the Alocasia Princeps Complex from upper hill forest on the extremely hard Paleogene sandstones of the Penrissen range, SW Sarawak. Alocasia puncakborneensis occurs at the highest altitude of any of the locally-restricted /geologically obligated species yet described for the Princeps Complex.
\end{abstract}

Keywords: Alocasia Princeps Complex, Sarawak, Penrissen Range.

\section{INTRODUCTION}

Alocasia Schott was last revised for Borneo by Hay (1998), recognizing 20 species of which eight were then described as new, while one probable novelty was left as incompletely known. Since then the incompletely known species was described (Hay 2000), and four entirely new species have been published (Boyce 2007; Kurniawan and Boyce 2011; Wong and Boyce 2016). Presently the Alocasia flora for Borneo stands at 24 described species, of which three - Alocasia longiloba Miq., A. princeps W.Bull, and A. scabriuscula N.E.Br. are largely each treated as taxonomically intractable species complexes, with the $A$. princeps and A. scabriuscula complexes seemingly related and treated by Hay (1998) together as forming the A. scariuscula Group. During the course of fieldwork since 2004 the authors have become aware of at least a further 10 undescribed Alocasia species occurring on Borneo but in many instances have yet to encounter the plants in a condition suitable to permit description while herbarium material, where it exists, is wholly inadequate. Occasionally, however, we encounter a new species flowering in habitat permitting formal description.

Here we describe one such novelty occurring on the extremely hard Paleogene sandstones of the Penrissen Range of SW Sarawak where it is 
restricted to moist upper hill forest above $800 \mathrm{~m}$. Geological occurrences in this paper are verified with Tate (2001).

\section{Alocasia puncakborneensis S.Y.Wong \& P.C.Boyce, sp. nov.}

Type: Malaysian Borneo, Sarawak, Kuching, Padawan, Puncak Borneo, trail to Batu Panggah, $1^{\circ} 07^{\prime} 37.0^{\prime \prime} \mathrm{N}$ $110^{\circ} 13^{\prime} 47.5^{\prime}$ E, $838 \mathrm{~m}$ asl. 15 May 2019, Wong Sin Yeng \& P. C. Boyce AL- 80 (holotype SAR!; isotype KEP!). (Figures $1 \& 2$ ).

\section{Diagnosis}

Alocasia puncakborneensis falls uncontroversially in the Alocasia Princeps Complex by the thinly leathery leaves, sequentially produced blooms not interspersed with foliage leaves, the staminate portion of the spadix partially enclosed within the lower spathe chamber, and the acroscopic pistils. Alocasia puncakborneensis is distinguished from all described species of the complex by the brilliant green leaf blades with the tertiary veins forming a prominently raised fine reticulum on the adaxial surface.

\section{Description}

Small herb to ca $55 \mathrm{~cm}$ tall; rhizome initially condensed, erect, later elongating and decumbent, ca $3 \mathrm{~cm}$ diam.; leaves several together, irregularly interspersed with slightly fleshy pale green, later marcescent brown lanceolate cataphylls to ca $9 \mathrm{~cm}$ long; petioles $10-45 \mathrm{~cm}$ long, ca $5 \mathrm{~mm}$ diam., semi glossy pale green sheathing in the lower ca $10-15 \%$; blades thinly leathery, in adult plants all peltate or mixed peltate and non-peltate, only very occasionally entirely non-peltate, ovate to rather narrowly ovato-sagittate, $10 \times 4 \mathrm{~cm}$ to $35 \times 11-12 \mathrm{~cm}$, widest at or slightly distal to junction of petiole, glossy brilliant green with the adaxial surface densely and finely raised-reticulate; anterior lobe acute, with the tip abruptly acuminate for $\mathrm{ca} 1 \mathrm{~cm}$; anterior costa with $3-4(-5)$ primary lateral veins on each side, diverging at ca. $90^{\circ}$ proximally, the distal ones at ca $60^{\circ}$, running almost straight to the margin and joining a submarginal vein; axillary glands not conspicuous; secondary venation fine, forming a rather vague interprimary collective vein, very slightly impressed adaxially, flush with the lamina abaxially but slightly darker and thus visible; tertiary veins forming a fine reticulum, prominently raised adaxially, flush abaxially; posterior lobes about $1 / 5$ the length of the anterior, united for $75-90 \%$ of their length, or free, when maximally united the base of the blade slightly rounded except for an acute to rather obtuse notch; posterior costae diverging at ca $15^{\circ}$ when blade peltate, or at ca $30^{\circ}$ when not peltate, so posterior lobes not widely divergent, and naked in the sinus for ca $2 \mathrm{~cm}$; inflorescences 2-4 together, subtended by lanceolate rather fleshy cataphylls, these later briefly marcescent, brown; peduncle ca $10 \mathrm{~cm}$ long at anthesis, extending to about twice this during fruiting; spathe ca $6 \mathrm{~cm}$ long; lower spathe ca $2 \mathrm{~cm}$ long, ovoid, semi glossy white; limb semi glossy white on both surfaces, at first erect, then sharply deflected, oblong lanceolate, mucronate for ca. $6 \mathrm{~mm}$; spadix slightly shorter than the spathe, stipitate for ca $3 \mathrm{~mm}$, stipe semi glossy white; pistillate zone ca $1 \mathrm{~cm}$ long; pistillate florets somewhat lax, flask-shaped, ca $1.5 \mathrm{~mm}$ diam., facing obliquely upwards, ovary pale green, the stylar region somewhat darker; style slender, ca $0.5 \mathrm{~mm}$ long, in a few florets absent; stigma 2-lobed, white and shining/sticky; sterile interstice ca. $4 \mathrm{~mm}$ long, slighly attenuated, situated within the chamber of the lower spathe, lower synandrodia irregular in shape, ca. $2 \mathrm{~mm}$ diam., upper ones rhombo-hexagonal; staminate zone ca $2 \mathrm{~cm}$ long, $4 \mathrm{~mm}$ diam., subcylindric, slightly constricted ca $1 / 3$ from the base corresponding to spathe constriction; synandria rhombo-hexagonal ca. $2 \mathrm{~mm}$ diam., 4-6-merous, the thecae opening by apical pores, synconnective not expanded beyond the edge of the synandrium; appendix about isodiametric with staminate zone, ca. $2 \mathrm{~cm}$ long, gradually tapering to a blunt point, appendical staminodes irregularly polygonal, pale cream; fruiting spathe broadly ovoid, ca. $2 \mathrm{~cm}$ long, brilliant white, remaining erect, persistent lower spathe splitting longitidinally into about three segments; berries bright scarlet.

\section{Etymology}

The specific epithet is from the Type locality plus the suffix -ensis, indicating 'from'. Puncak (summit of a mountain in the Malay language) is pronounced punchak, with emphasis on the second syllable.

\section{Distribution}

Occurring as localised small populations and occasional individuals throughout the higher reaches of the Penrissen Range, never below $800 \mathrm{~m}$, and extending to about $1300 \mathrm{~m}$ asl.

\section{Ecology}

Terrestrial or facultatively lithophytic on steep shaded slopes or on damp boulders under moist upper hill forest on Paleogene sandstones, between 880-1170 m asl. 


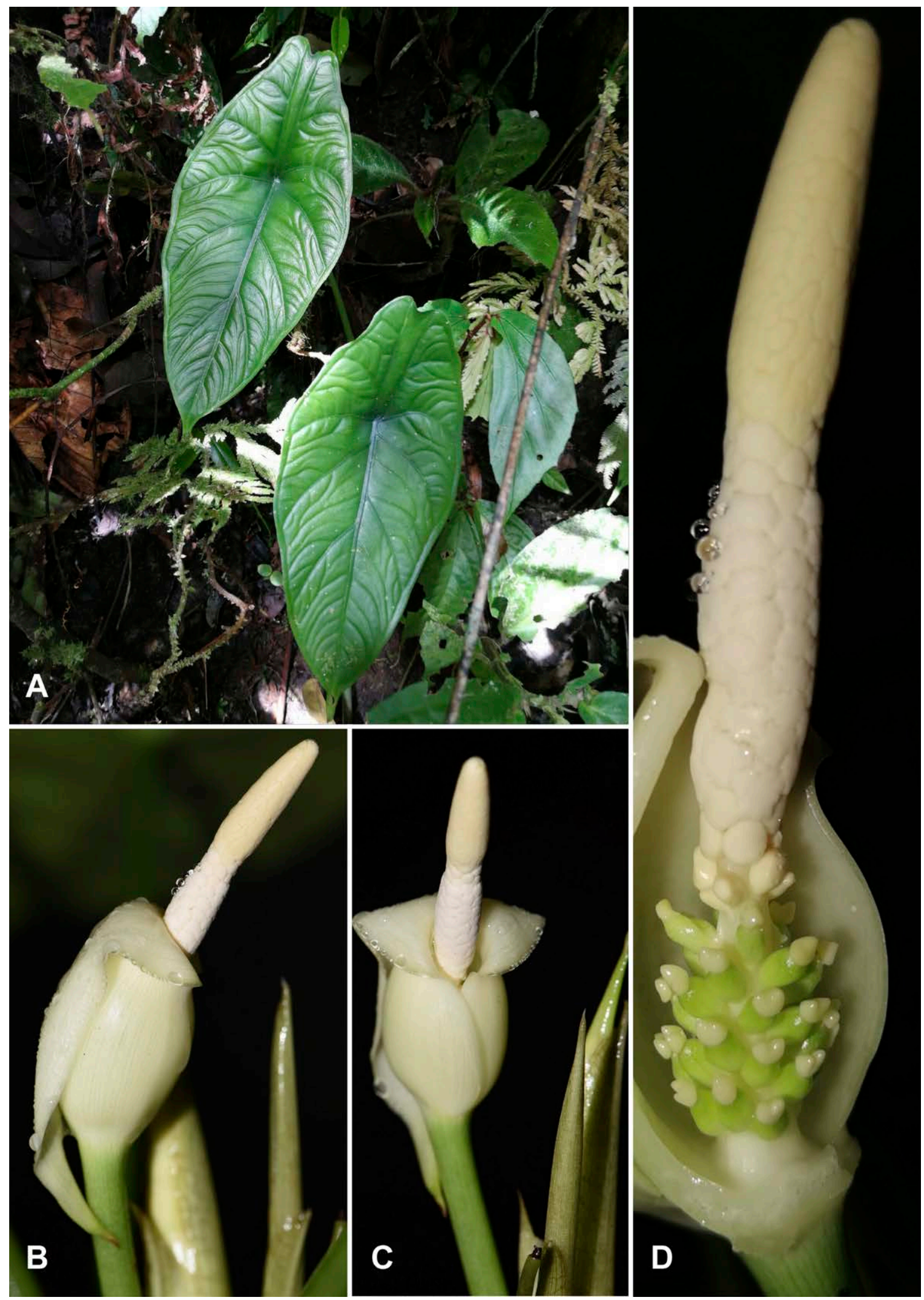

Figure 1. Alocasia puncakborneensis (A) Plants with fully peltate posterior lobes in habitat. (B \& C) Inflorescence at pistillate anthesis. (D) Spadix at pistillate anthesis with the nearside spathe artificially removed. A, unvouchered; B - D from $A L-80$. 


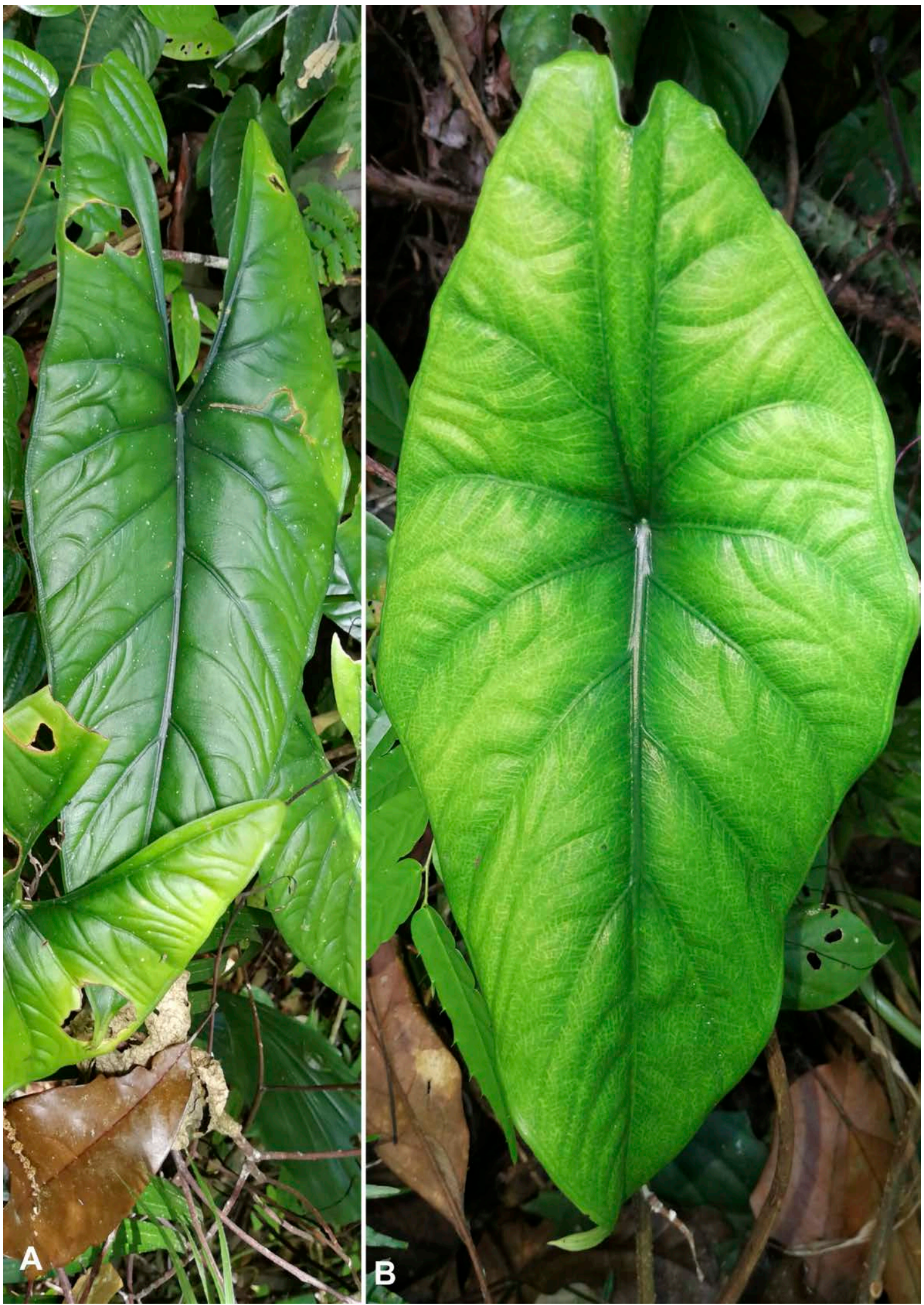

Figure 2. Alocasia puncakborneensis (A) Leaf blade with posterior lobes none peltate. (B) Leaf blade with peltate posterior lobes. Both unvouchered. 


\section{Notes}

Alocasia puncakborneensis occurs at the highest altitude of any of the locally-restricted /geologically obligated species yet described for the Princeps Complex. Six of the eight hitherto known species are lowland species, exceptionally occurring up to $600 \mathrm{~m}$ asl, and mostly much lower, and are obligated to Karst limestone (Hay 1998). Three of these species occur in Sabah (Alocasia pangeran A.Hay, A. principiculus A.Hay, Alocasia puteri A.Hay), one in east Sarawak (A. venusta A.Hay), and two in SW Sarawak (A. reversa N.E.Br., A. ridleyi A.Hay). One of the remaining species, Alocasia wongii A.Hay, occurs across quite a wide area of east Sabah, usually at low altitudes on sandy sedimentary-derived substrates, although occasionally occurring on limestone. As currently defined Alocasia princeps W.Bull is widespread throughout middle and east Borneo at up to $1200 \mathrm{~m}$ asl, is ecologically highly inconstant, and morphologically rather variable. Detailed field studies will in all likelihood reveal the current concept to consist of more narrowly defined taxa (see Hay 1998 for more detailed discussion).

\section{ACKNOWLEDGEMENTS}

Fieldwork was most recently under Sarawak Forestry Department Permission to Conduct Research on Biological Resources - Permit No. (67) JHS/NCCD/6007/2/107/Jld.2 and Park Permit No WL33/2019. The collaboration and support of the Sarawak Forestry Department and the Sarawak Biodiversity Centre are gratefully acknowledged. The last author extends his thanks to Tan Sri Datuk Amar Leonard Linggi Anak Jugah and Malesiana Tropicals Sdn Bhd for continued support and encouragement.

\section{REFERENCES}

Boyce PC. 2007. Studies on the Alocasia Schott (Araceae - Colocasieae) of Borneo: I. Two new species from Sarawak, Malaysian Borneo. Gardens' Bulletin Singapore 58: 141-154.

Hay A. 1998. The genus Alocasia (Araceae-Colocasieae) in West Malesia and Sulawesi. Gardens' Bulletin Singapore 50: 221-334

Hay A. 2000. Alocasia nebula. Botanical Magazine, n.s. 17(1): 14-18, pl. 381

Kurniawan A, Boyce PC. 2011. Studies on the Alocasia Schott (Araceae-Colocasieae) of Borneo II: Alocasia baginda, a new species from East Kalimantan, Indo- nesian Borneo. Acta Phytotaxonomica et Geobotanica 60(3): 123-126.

Tate RB. 2001. The geology of Borneo island CDROM. Kuala Lumpur: Persatuan Geologi Malaysia / Geological Society of Malaysia.

Wong KM, Boyce PC. 2016. Novitates Bruneienses, 6. Alocasia azlanii (Araceae), a new species from Brunei. Acta Phytotaxonomica et Geobotanica 67(3): 185-189. 